\title{
Pengembangan Model Pembelajaran Gerak Dasar Lokomotor Pada Siswa SD Kelas V
}

\author{
Amirzan \\ Correspondence: Universitas Jabal Ghafur, Aceh, Indonesia \\ E-mail: amirzan.masry@gmail.com
}

\begin{abstract}
Abstrak
Gerak dasar terdiri dari gerak lokomotor, non loko motor dan manipulatife yang harus dapat dilakukan anak dengan benar, sehingga perkembangan gerak yang ia miliki kelak akan dapat mendukung setiap aktivitas gerak yang ia lakukan. Penelitian ini membahas tentang gerak dasar lokomotor yang berkaitan dengan gerak dasar. Penelitian ini adalah penelitian pengembangan Model Pembelajaran Gerak Dasar Lokomotor (PGDL), objek penelitian pada sekolah dasar paforit yang ada di Kecamatan Kota Sigli Kabupaten Pidie Propinsi Aceh, yakni; SDN 2 Percontohan Tijue, SD dan SD Unggul Iqra' Sigli dengan jumlah sampekl secara keseluruhan 61 orang siswa, metode pengembangan mengacu pada metode yang dikemukakan oleh Borg dan Gall. Pengembangan model pembelajaran PGDL telah memenuhi kriteria syarat penerapan suatu model seperti: sintaksis (syntax), sistem sosial (social system), prinsip reaksi (principles of reaksi), sistem pendukung (support system), serta dampak instruksional dan dampak pengiring (instructional and nurturant effects). Dari hasil uji efektifitas model, terbukti secara empiris bahwa hasil produk berupa model pembelajaran gerak dasar lokomotor untuk Sekolah Dasar kelas V memiliki efektifitas yang sangat baik. Dengan kata lain, model pembelajaran gerak dasar lokomotor ini efektif untuk menunjang proses pembelajaran PJOK di Sekolah Dasar terutama papa tingkat kelas $V$.
\end{abstract}

\section{Kata Kunci: Status Gizi, Kebugaran Jasmani}

\section{Pendahuluan}

Proses pembelajaran yang dilaksanakan di kelas $\mathrm{V}$ tidak terlepas dari aktifitas pembinaan dan pengembangan kemampuan gerak multi lateral siswa sehingga nantinya akan diharapkan adanya suatu gerakan yang komplek dan sempurna manakala diarahkan pada satu cabang olahraga yang akan digelutinya kelak, dengan harapan akan mampu meraih atau memperoleh prestasi yang merupakan sasaran akhir dari setiap pemusatan pembinaan jasmani. Hal ini tentu membutuhkan tingkat ke akuratan dan kemampuan guru untuk mengarahkan minat dan bakat olahraga peserta didiknya. Sedangkan bila dikaitkan dengan intlegensi siswa adalah bila pembelajaran gerak komplek dilakukan secara teratur akan berpengaruh terhadap peningkatan kemampuan kognisi siswa yang pada akhirnya akan meningkatkan prestasi belajar siswa.

PJKR

http://jurnal.unimed.ac.id/2012/index.php/jpehr/index 
Gerakan multilateral adalah bentuk dari keseluruhan gerak dasar manusia seperti ; gerak lokomotor atau gerakan berpindah tempat yakni berjalan, melompat, merayap berguling, selanjutnya gerak non lokomotor adalah gerakan yang tanpa berpindah tempat tetapi menggerakkan kemampuan kelentukan sendi ke segala arah seperti meliukkan badan, memutar bahu, mengangkat kaki, melakukan gerakan keseimbangan dengan berbagai bentuk gerakan kelentukan dan selanjutnya gerak lokomotor adalah segala bentuk gerakan yang menggunakan berbagai alat seperti menendang bola, melempar benda dan dalam bentuk permainan dengan alat lainnya. Tudor O. Bompa dan G. Gregory Haff (1999: 3) Mengatakan pembangunan fisik multilateral fisik: Olahraga pembangunan fisik yang spesifik, atau general fitness seperti yang juga kita kenal, memberikan latihan dasar untuk sukses dalam semua olahraga. Jenis sasaran pembangunan peningkatan kekmampuan biomotor dasar, seperti daya tahan, kekuata, kecepatan, fleksibelitas dan koordinasi. Atlet yang mengmbangkan dasar yang kuat akan dapat mentoleransi lebih baik kegiatan-kegiatan latihan olahraga spesifik dan pada akhirnya memiliki potensi yang lebih besar untuk pengembangan atlet.

Kesemua gerakan tersebut harus diterapkan dalam proses belajar mengajar matapelajaran Pendidikan Jasmani, Olahraga dan Kesehatan di kelas V dan hal ini sesuai dengan kurikulum, guru berusaha agar aktifitas belajar dapat berlangsung dengan suasana yang menyenangkan dan nyaman bagi siswa, sehingga siswa tidak merasa bosan dalam berolahraga yang dapat berdampak lebih banyak siswa menempatkan dirinya sebagai penonton dari pada ikut terlibat aktif. Adang Suherman dan Hadi Sartono (2008: 4) Menyatakan, seharusnya guru membangun kondisi dimana seluruh anak terlibat aktif mengembangkan petensi fisiknya dalam suasana yang menyenangkan, saling menghargai, saling mendukung, bekerja sama, toleransi, disiplin dan sportif untuk menggali dan melakukan pengalaman gerak seluas-luasnya untuk membina potensi motorik mereka kelak. Maka beberapa aktivitas yang seringkali diberikan dalam suatu program pendidikan jasmani adalah: aktivitas lokomotor, mengontrol obyek, kesegaran jasmani, aktivitas sosial, "body management", permainan, dan keterampilan olahraga.

Pada Sekolah Dasar baik di wilayah UPTD (Unit Peayanan Tingkat Dasar) Kecamatan Kota Sigli Kabupaten Pidie Propinsi Aceh merupakan basis untuk pengembangan setiap pola-pola pembelajaran yang dianggap baru terutama untuk matapelajaran Pendidikan Jasmani, Olahraga dan Kesehatan karena merupakan pusat kota kabupaten, artinya bahwa guru penjas orkes dan guru kelas di kecamatan kota selalu paling awal menerima pembinaan atau penataran setiap perubahan sistem yang baru di dunia pendidikan terutama berkaitan dengan perubahan kurikulum maupun perubahan aturan dan sistem pendidikan, sehingga secara menyeluruh di semua Sekolah Dasar selalu akan berpedoman berdasarkan pemahaman pembelajaran yang dimiliki oleh guru kelas atau guru Pendidikan

PJKR 
Jasmani, Olahraga dan Kesehatan di sekolah percontohan maupun sekolah unggul yang ada, dengan demikian dapat difahami adanya perbedaan yang harus diupayakan menjadi satu kesatuan sistem yang baik untuk dipedomani oleh para guru.

\section{Pustaka}

Model Pengembangan oleh Sugiono, Secara ringkas memberikan penjelasannya sebagai berikut: 1) Potensi dan masalah; R\&D dapat berangkat dari adanya potensi dan masalah, 2) Mengumpulkan informasi; setelah potensi dan masalah dapat ditunjukkan dengan data secara faktual, dan selanjutnya perlu dikumpulkan dari berbagai informasi yang dapat digunakan sebagai bahan untuk perencanaan, 3) Desain produk; adalah hasil akhir dari suatu serangkaian penelitian awal, dapat berupa rancangan kerja baru, atau produk baru, 4) Validasi desain; proses untuk menilai apakah rancangan kerja baru atau produk baru secara rasional lebih baik dan efektif dibanding dengan yang lama, dengan cara meminta penilaian dari para ahli yang berpengalaman, 5) Perbaikan desain; Diperbaiki atau direvisi setelah diketahui ada kelemahannya, 6) Uji coba produk; melakukan uji coba lapangan terbatas dengan eksperiment, 7) Revisi produk; direvisi dengan berdasar uji lapangan/empiris, 8) Uji coba pemakaian; dilakukan suatu uji coba dalam kondisi yang sesungguhnya, 9) Revisi produk; apabila ada kekurangan saat penggunaan dalam kondisi sesungguhnya, maka produk diperbaiki, 10) Pembuatan produk massal; setelah model diperbaiki, hasil akhirnya siap diproduksi secara massal.

Model Pengembangan James $\mathrm{T}$ Botis, R\&D ada yang berjangka panjang seperti yang ditunjukkan James T. Bontis dalam "Long Range Energy R\&D: $A$ Methodology for Program Development and Evaluation”. Beragam tahapan dan proses R\&D dari bermacam bidang telah dijelaskan. Yang terlihat dengan sangat jelas adalah tahapan dan proses $R \& D$ tidak tunggal dan seragam. Ada yang sederhana, terdapat pula yang kompleks. Ada yang linier, siklis, dan gabungan keduanya. Para peneliti bebas memilih sesuai dengan tujuan dan bidang masingmasing. Tentu saja yang hendak mengembangkan prosudur kerja yang baru, atau akan memimilih tahapan-tahapan dan proses yang tidak sama dengan yang ingin mengembangkan sebuah model pembelajaran dari memanfaatkan internet. Meski ada perbedaan dalam tahapan dan proses, pada prinsipnya terdapat sejumlah kesamaan seperti contoh-contoh di atas.

Model Pengembangan 4-D, model pengembangan 4-D (Four D) merupakan model pengembangan pada perangkat pembelajaran. Model ini juga dikembangkan oleh S. Thagarajan, Dorothy S. Semmel, dan Melvyn I. Semmel. Model pengembangan 4D terdiri atas 4 tahap utama yaitu: (1) Defme (Pembatasan); (2) Design (Perancangan); (3) Develop (Pengembangan); dan

PJKR 
Disseminate (penyebaran), atau diadaptasi Model 4-P, yaitu Pendefinisian, Perancangan, Pengembangan dan Penyebaran (...). (Trianto, 2007, 61-66).

Model Penelitian Pengembangan Borg dan Gall, menurut Borg dan Gall langkah-langkah atau siklus dari pengembangan model yakni: Meneliti dan mengumpulkan informasi (literatur, pengematan kelas, persiapan laporan tentang pokok persoalan). 1) Perencanaan (Pembatasan persoalan, perumusan tujuan, urutan penyajian, uji coba dengan skala kecil), 2) Penyiapan produk awal (Penyiapan materi, buku pegangan dan perlengkapan evaluasi), 3) Uji lapangan pendahuluan, 4) Revisi produk utama (Sesuai dengan saran pada hasil uji lapangan pada pendahuluan), 5) Uji lapangan utama: (Yakni melibatkan subjek yang lebih luas (5-15) sekolah), 6) Revisi produk oprasional (dari saran uji lapangan utama), 7) Uji lapangan oprasional (dilakukan pada 10-13 sekolah), data wawancara, observasi dan kuessioner dikumpulkan dan di analisis, 8) Revisi produk akhir (dari saran uji lapangan oprasional), 9) Desiminasi dan implementasi produk.

Model Assure, langkahpenting yang perlu dilakukan dalam model desain sistem pembelajaran Assure meliputi beberapa aktivitas yaitu: (a) Melakukan analisis karakteristik siswa/ analyzelearners,(b) menetapkan tujuan pembelajaran/ stateobjectives,(c) Memiilih media, metode pembelajaran, dan bahan ajar/ select methods, media, and materials, (d) memanfaatkan bahan ajar/ utilize materials (e) Melibatkan siswa dalam kegiatan pembelajaran/ require learners participation, dan, (f) Mengevaluasi dan merevisi terhadap program pembelajaran/ evaluate and revisi. (Benny A. Pribadi, 2010: 100).

Pengembangan dari model pembelajaran-pembelajaran gerak dasar lokomotor dilakukan dengan bertujuan lebih meningkatkan tingkat efesiensi dan efektifnya suatu proses belajar mengajar di sekolah. Dari suatu pemikiran konstruktif menyatakan bahwa belajar bukanlah hanya sekedar mengingat untuk memahami dan menerima ilmu pengetahuan, mereka harus bekerja untuk memecahkan masalah, mencari dan menemukan sesuatu bagi dirinya dan selalu berusaha menganalisa dan menemukan ide-ide kreatif. Peranan guru bukan hanya menuangkan sejumlah informasi ke benak siswa, tetapi mengusahakan agar bagaimana konsep-konsep penting yang sangat berguna tertanam kuat dalam benak atau ingatan siswa.

Robert Gigne membedakan delapan tipe belajar yakni :1) Signal learning (belajar isyarat), 2) stimulusrespons learning, 3) Chaining (rantai atau rangkaian), 4) verbal association (asosiasi verbal), 5) discrimination learning (belajar diskriminasi), 6) concept learning (belajar konsep), 7)rule learning(belajar aturan), 8) problem solving(pemecahan maslah).

Constructivism (konstruktifsme) merupakan landasan berpikir (filosofi) yaitu bahwa pengetahuan dibangun oleh manusia sedikit demi sedikit yang

PJKR

http://jurnal.unimed.ac.id/2012/index.php/jpehr/index 
hasilnya diperluas melalui konteks yang terbatas (sempit) dan tidak sekonyongkonyong. Pengetahuan bukanlah seperangkat pakta-pakta, konsep atau kaidah yang siap untuk diambil dan diingat. Manusia harus mampu mengkonstruksi pengetahuan itu dan memberikan makna melalui pengalaman nyata.

Siswa perlu dibiasakan untuk memecahkan masalah, menemukan sesuatu yang berguna bagi dirinya dan bergelut dengan ide-ide, guru tidak akan mampu memberikan pengetahuan kepada para siswa. Siswa harus mengkonstruksikan pengetahuan di benak mereka sendiri. Esensi dari teori konstruktivis adalah ide bahwa siswa harus menemukan dan mentransformasikan suatu informasi kompleks ke situasi lain dan apabila dikehendaki, informasi itu menjadi milik mereka sendiri.

Toeri Bandura menyatakan bahwa belajar observasioanal terjadi secara independen dari penguatan bukan berarti bahwa variable-variable lainnya tidak mempengaruhinya. Pemodelan merupakan konsep dasar dari teori belajar social yang dikembangkan oleh Albert Bandura. Menurut Bandura sebagian besar manusia belajar melalui pengamatan secara selektif dan mengingat tingkah laku orang lain, sehingga kedua inter prestasi tersebut akan melahirakan pemahaman. Seseorang belajar menurut teori Bandura ini dilakukan dengan mengamati tingkah laku orang lain (dalam hal ini model), hasil pengamatan itu kemudian dimantapkan denganmenghubungkan pengalaman baru.

Menurut teori ini, tujuan dari belajar adalah kegiatan untuk memanusiakan manusia. Proses belajar dianggap berhasil jika pembelajar telah memahami lingkungannya dan dirinya sendiri. Siswa dalam proses belajarnya harus berusaha agar lambat laun ia mampu mencapai aktualisasi diri dengan sebaik-baiknya. Teori belajar ini berusaha memahami perilaku belajar dari sudut pandang pelakunya, bukan sudut pandang pengamatnya. Maka Humanisme merupakan filsafat hidup yang intinya adalah memanusiakan manusia yaitu yang mempunyai komitmen untuk terwujudnya manusia seutuhnya meliputi semua aspek perkembangan positif pribadi seperti cinta, kreativitas, makna, dan sebagainya. Setiap pribadi mempunyai kemampuan dan tanggungjawab atas kehidupannya yang mengarah pada kepentingan kemanusiaan. (Yusuf Hadi Miarso, 2007: 53).

Selanjutnya Joeyce and Wiel menyatakan bahwa: "Models of teaching are really models of learning. As we help student acquire information, ideas, skills, value, ways of thinking and means of expressing themselves, we are also teaching them how to learn". (Bruce Joyce dan Marsha Weil, Marsha Well dan Emily Calhoun, 2011: 7-9).

Pengertian-pengertian dari pendidikan jasmani dapat dibedakan dari dua sudut pandang, yaitu secara tradisional dan modern. Pandangan tradisional menganggap manusia terdiri dari dua komponen utama yang dapat dipilah-pilah, yaitu jasmani dan rahani (dikotomi). Oleh karena itu pendidikan jasmani diartikan

PJKR 
sebagai proses pendidikan untuk keselarasan antara tumbuhnya badan dan perkembangan jiwa. Sedangkan pandangan modern terhadap manusia sebagai satu kesatuan yang utuh (holistik). Oleh Karena itu pendidikan jasmani adalah dasar proses pendidikan melalui aktivitas jasmani sekaligus merupakan proses pendidikan untuk meningkatkan kemampuan jasmani. Oleh Skinner kedua pengertian tersebut sebagai education for the physical dan education throught the physical bukan menggantikan education for the physical, tetapi melanjutkannya sehingga tujuan pendidikan jasmani dapat secara menyeluruh. Pendidikan jasmani merupakanbagianintegral dari pendidikan secara keseluruhan melaluiberbagai kegiatan jasmani yang bertujuan mengembangkan individu secara organik. Neuro muskuler, intelektual, dan emosional.

Badan Standar Nasional Pendidikan (BSNP) yang telah mendeskripsikan bahwa pendidikan jasmani adalah suatu proses pembelajaran melalui aktivitas jasmani yang didesain untuk meningkatkan kebugaran jasmani, mengembangkan keterampilan motorik, pengetahuan dan perilaku hidup sehat dan aktif, sikap sportif, dan kecerdasan emosi. Lingkungan belajar diatur secara seksama dan meningkatkan pertumbuhan dan perkembangan seluruh ranah, seprti jasmani, psikomotor, kognitif, dan afektif setiap siswa.

Berarti pendidikan jasmani tidak hanya mengembangkan, ranah motorik saja, tetapi harus sampai mampu mengembangkan ranah kognisi dan afeksi. Dengar demikian pendidikan jasmani. Bukan sekedar pendidikan untuk jasmani (education for the physical) tetapi berupa pendidikan menalui jasmani(education for througt the physical). Namun demikian, bagaimana mampu melakukan pendidikan melalui jasmani apabila jasmaninya belum terbentuk. Hal tersebut sesuai dengan pendidikan jasmani yang mementingkan pencapaian yang dikemukakan Skinner (1976), yaitu; Physical development; physical skill basic and recreation; individual emotional development; social development-human relation skill; dan fun.

Seperti dijelaskan oleh Ken Green. The twin ideas of developing sporting skills (in order to facilitate participation in sport as a valued cultural practice) and justifying sport as a vehicle for imforming and developing the mind are also to be found in the Position Statement on Physical Education of what, until recently, was the lead body for PE in the UK (the Physical Education Association of the United Kingdom (PEA-UK $\left.{ }^{4}\right)$, which stated that PE involves both 'learning to move' and 'moving to learn'.(Ken Green. Ltd. 2011: 16).

Karakteristik Siswa di sekolah dasar dapat dibagi menjadi dua, yaitu kelas rendah dan kelas tinggi. Kelas rendah terdiri dari kelas satu, dua, dan tiga, sedangkan kelas-kelas tinggi terdiri dari kelas empat, lima, dan enam. Di Indonesia, rentang usia siswa SD, yaitu antara 6 atau 7 tahun sampai 12 tahun. Usia siswa pada kelompok, yaitu 6 atau 7 sampai 8 atau 9 tahun. Siswa yang

PJKR 
berada pada kelompok ini termasuk dalam rentangan anak usia dini. Masa usia dini ini merupakan masa yang pendek tetapi sangat penting bagi kehidupan seseorang. Oleh karena itu, pada masa ini seluruh potensi yang dimiliki anak perlu didorong sehingga akan berkembang secara optimal.

Beberapa keterampilan akan dimiliki oleh anak yang sudah mencapai beberapa tugas-tugas perkembangan pada masa kanak- kanak akhir dengan rentang usia 6-13 tahun. Keterampilan yang dicapai diantaranya, yaitu social-help 2 skills dan play skill. Social-help skills berguna untuk membantu orang lain di rumah, di sekolah, dan di tempat bermain seperti membersihkan halaman dan merapikan meja kursi. Keterampilan ini akan menambah perasaan harga diri dan menjadikannya sebagai anak yang berguna, sehingga anak suka bekerja sama (bersifat kooperatif).

Perkembangan gerak dasar anak sekolah dasar dibagi menjadi tiga periode yaitu: (1) fase perkembangan gerak dasar usia 2-7 tahun; (2) fase transisi usia 7-10 tahun; (3) fase spesifikasi 10-13 tahun. (M. Yudha Saputra, $2001: 14$ ) Pada fase perkembangan gerak dasar usia 2-7 tahun, anak mulai belajar berjalan pada saat mereka berusia kira-kira dua tahun dan bentuk-bentuk lain gerak lokomotor. Anak berusia 2-7 tahun pada dasarnya sedang mengalami masa pertumbuhan, mengalami bertambahnya pengalaman, mereka bergantung pada instruksi dan meniru. Mereka menjadi lebih terampil menguasai keterampilan gerak dasar. Pada fase ini anak sudah siap untuk menerima informasi dari guru. Guru dapat memberikan keterampilan persepsi motorik, keterampilan multilateral dan keterampilan terpadu.

Multi lateral atau multiskil dikembangkan oleh negara Eropa Timur, dimana sekolah melakukan program latihan dasar untuk mengembangkan keterampilan pokok seperti: lari/jalan, melompat, melempar, menangkap, berguling dan menjaga keseimbangan. Anak-anak yang berhasil sangat baik meng-koordinasikan dan memperoleh keterampilan yang merupakan dasar kesuksesan, baik olahraga perorangan dan beregu, seperti atletik, bola basket dan sepakbola, juga ada program berenang yang mengembangkan kapasitas aerobik. (James Tangkudung, 2012 8-9).

Pada fase spesifikasi usia 10-13 tahun ini, anak sudah dapat menentukan pilihannya akan cabang olahraga yang disukainya, secara umum mereka sudah memiliki kemampuan dan koordinasi dan kelincahan yang jauh lebih baik. Pada fase ini mereka memilih untuk mengkhususkan pada salah satu cabang olahraga yang dianggap mampu untuk dilakukan. Mereka juga sudah mulai bisa menilai kelebihan dan kekurangan yang dimilikinya. Anak mulai mencari atau menghindari aktivitas yang tidak disukainya. (Yudanto, 200: 14). Hakekat perkembangan keterampilan gerak bagi anak sekolah dasar ditekankan sebagai perkembangan dan penghalusan aneka keterampilan gerak dasar dan keterampilan

PJKR 
gerak yang berkaitan dengan olahraga. Pada dasarnya gerak dasar merupakan gerak yang bersifat umum yang apabila dikuasai oleh siswa sekolah dasar, akan menjadi landasan yang kokoh untuk dapat mengembangkan gerak- gerak yang lebih kompleks. Gerak dasar pada anak membentuk dasar untuk gerak. Gerak dasar terdiri dari gerakan lokomotor, non lokomotor dan manipulatif.

Gerak lokomotor adalah gerak memindahkan tubuh dari satu tempat ke tempat yang lain. Bentuk gerak lokomotor diantaranya berjalan, berlari, berjingkat ,melompat dan meloncat, berderap, merayap dan memanjat termasuk berenang. Bahwa pada pembahasan sebelumnya telah diuraikan bawa model pembelajaran gerak dasar lokomotor (PGDL) didasari oleh beberapa toeri belajar yang beraliran behavioristik, kognitivistik, maupun gabungan kedua aliran tersebut yakni konvergensi, yang mana pendidikan dipengaruhi oleh dua factor yakni faktor internal dan ekternal, faktor internal adalah faktor yang berkaitan dengan fisik dan mental siswa, sedangkan faktor eksternal adalah faktor diluar diri siswa yakni leingkungan sosial.

Dari beberapa model yang penulis pantau di lapangan belum sepenuhnya menganut model pembelajaran yang menyenangkan dan dengan sistem pembelajaran tematis seperti yang diharuskan dalam proses pembelajaran Pendidikan Jasmani dan Olahraga di Sekolah Dasar, oleh karena itu penulis akan merancang suatu bentuk pembelajaran yang mendasari kurikulum dengan pembelajaran yang dimodifikasi, namun demikian komponen-komponen pengembangan tersebut diadaptasi dengan model pembelajaran yang ada dan akan dikembangkan kemudian kearah pembelajaran yang lebih efektif, sehingga diharapkan model tersebut lebih baik dari model sebelumnya. Oleh sebab itu maka penulis memilih, yakni Model Pembelajaran Gerak Dasar Lokomotor (PGDL) dengan model pengembangan yang dikemukakan oleh Borg and Gall.

\section{Metode}

Penelitian pengembangan ini mempedomani draft model yang dikemukakan oleh Borg and Gall, dengan sepuluh langkah untuk pengembangan dimulai dari; 1. Melakukan penelitian pendahuluan (prasurvei). 2. Perencanaan, 3. Mengembangkan jenis/bentuk produk awal, 4. Melakukan uji coba lapangan, 5. Melakukan revisi produk utama, 6. Uji coba lapangan utama (lebih luas), 7. Revisi terhadap produk operasional, 8. Uji lapangan oprasional (uji kelayakan), 9. Revisi terhadap produk akhir (revisi final) dan, 10. Mendesiminasikan dan meng implementasikan produk. 


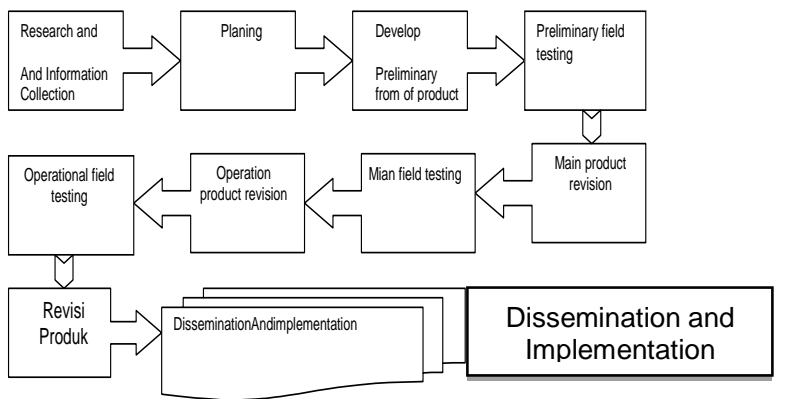

Gambar 1. Tahap Pengembangan Model Borg and Gall

(Borg, W.R. \& Gall, M.D, 2005: 590).

Namun secara garis besar dibagi dalam tiga tahap pengmbangan yakni; 1 . Tahap identifikasi dan anlisis kebutuhan, 2. Tahap pengembangan design dan draf model, 3. Tahap pengujian (tinjauan ahli, uji coba kelompok kecil dan uji coba lapangan). Uji coba kelompok kecil dilakukan di SD Negeri 2 Percontohan Tijue, uji coba lapangan juga dilakukan di SD Negeri 2 Percontohan Tijue dan siswa SDS Unggul Iqra'.

Pada uji coba kelompok besar (uji lapangan) yakni pada evaluasi tahap III, pengujian dilakukan dengan study eksperimen, untuk menganalisa efektifitas model PGDL pada mata pelajaran penjasorkes Kelas V SD. Eksperimen dilakukan dengan cara membandingkan keadaan sebelum dan sesudah menerapkan PGDL (before-after eksperimen).Uji coba kelompok besar dilaksanakan pada jumlah siswa yang lebih banyak dan lebih heterogen dan dilakukan dua kali. Untuk mengetahui efektivitas model PGDL dalam meningkatkan hasil belajar siswa kelas V SD, maka design data dianalisis dengan menggunakan statistik infrensial dengan uji-t menggunakan jasa bantuan computer SPSS 20,00 pada taraf significansi $(\alpha)=0,05$.

Langkah-langkah yang dilakukan pada kegiatan penelitian lapangan adalah sebagai berikut: (1) menetapkan kelompok subyek penelitian; (2) melaksanakan pre-test; (3) mencobakan model pembelajaran gerak dasar lokomotor (PGDL);(4) melaksanakan post-test; (5) mencari skor rata-rata hasil pre-test dan post-test, lalu membandingkan keduanya; (6) menentukan uji normalitas data serta menentukan homogenitas data; dan (7) mencari selisih perbedaan kedua rata-rata tersebut melalui metode statistik (uji-t) amatan ulangan untuk mengetahui apakah terdapat pengaruh yang signifikan dari penggunaan model pembelajaran.

\section{Pembahasan}

Dari hasil validasi uji ahli, uji coba kelompok kecil, dan uji coba lapangan, maka pada dasarnya pengembangan model pembelajaran PGDL telah memenuhi kriteria atau syarat penerapan suatu model pembelajaran yakni: sintaksis (syntax),

PRKR

http://jurnal.unimed.ac.id/2012/index.php/jpehr/index 
sistem sosial (social system), prinsip reaksi (principles of reaksi), sistem pendukung (support system), serta dampak instruksional dan dampak pengiring (instructional and nurturant effects).

Model PGDL juga telah memenuhi syarat validitas, praktis, dan efektif, dimana hasil penelitian menunjukkan: a) Secara umum atau $100 \%$ validator menyatakan draft awal model PGDL didasari atas teori yang kuat, b) Semua validator $(100 \%)$ menyatakan komponen-komponen model memiliki keterkaitan yang saling mendukung antara yang satu dengan yang lainnya. Dengan demikian draft model awal model PGDL telah memenuhi kreteria validitas, c) Model dinyatakan praktis, karena secara umum atau $80 \%$ validator menyatakan model PGDL dapat diterapkan di lapangan atau di kelas $\mathrm{V}$, artinya guru dapat menerapkan bentuk-bentuk permainan pada model-model pembelajaran ini baik di kelas maupun di lapangan, d) Hasil uji coba kelompok kecil secara keseluruhan rerata keterlaksanaan model adalah $=85,90 \%$ yang berarti bahwa tingkat keterlaksanaan model berada pada kategori "sangat tinggi", e) Efektivitas model PGDL, dari hasil uji coba kelompok kecil yang terlihat dari aktivitas siswa, hasil belajar dan tanggapan siswa terhadap model telah memenuhi persyaratan yang mana rerata aktivitas siswa $=91,64$ Setelah dikomversikan ke dalam tabel penggolongan aktivitas belajar siswa, sehingga untuk perolehan nilai rerata tersebut tergolong dalam ketegori aktivitas belajar pada kriteria sangat tinggi, f). Hasil uji lapangan dan uji produk, tingkat signifikansi keefektifan model berada di daerah penerimaan hipotesa atau berada di bawah $\alpha=0,05$, dengan demikian hasil uji efektifitas model, terbukti secara empiris hasil produk berupa model pembelajaran gerak dasar lokomotor(PGDL) untuk siswa Sekolah Dasar kelas V memiliki efektifitas yang sangat baik.

Hal ini ditunjukkan dengan hasil uji-t amatan ulangan terhadap kegiatan pengembangan dari (PGDL) ini, dengan indikator permainan yang mengarah pada kegiatan berlari, berjalan, melompat, meloncat, merayap, dalam bentuk permainan perorangan, berpasangan, beregu dan kelasikal, Sedangkan manfaat model terhadap gerakan yang menujukkan bahwa t-hitung pada kedua tes tersebut lebih besar dari $\mathrm{t}$-tabel. Dengan kata lain, model pembelajaran gerak dasar lokomotor dengan bentuk-bentuk permainanan yang sederhana namun efektif untuk meningkatkan kemampuan dan pengayaan gerak bagi siswa.

Berdasarkan analisis yang dikemukakan di atas, maka model pembelajaran PGDL telah memenuhi kriteria yakni valid, praktis dan efektif, artinya model PGDL adalah suatu model yang menciptakan sebuah pembelajaran PJOK yang dilandasi oleh teori yang kuat, komponen model yang saling berkatian antara satu sama lain, dapat diimplementasikan secara praktis di kelas atau di lapangan, dapat meningkatkan minat serta prestasi belajar siswa untuk berperan dan berpartisipasi aktif dalam setiap aktivitas pembelajaran PJOK di sekolah. Dengan mengikuti alur

PJKR 
pembelajaran kooperatif type STAD dan sintaksis pembelajaran, maka telah tampak serta mengikuti enam fase atau tahapaan pembelajaran yakni sebagai berikut; 1) menyampaikan tujuan, mempersiapkan dan memotivasi siswa (present goals and set). 2) menyaji/menyampaikan imformasi (present information), 3) mengorganisasikan kedalam kelompok-kelompok belajar (organize student into learning team), 4) membimbing kelompok bekerja dan belajar (assist team work and study), 5) Evaluasi (test on the materials) dan, 6) memberikan penghargaan (provide recognition).

Berikut akan disampaikan beberapa keunggulan dari produk ini antara lain: 1) adanya kejelasan sintaksis, sistem sosial dan sistem pendukung, kejalasan prinsif reaksi, terlaksananya harapan dampak instruksional dan dampak pengiring pada anak 2) memberikan pemahaman gerak bagi anak didik, 3) anak sangat gembira, 4) permainan dilakukan dari hal yang mudah ke yang sulit. 5) tingkat kompetisi yang tinggi 6) repetisi atau pengulangan gerakan dari materi yang diajarkan lebih banyak. 7) peserta didik dituntut berfikir secara cepat dan tepat, ketika dia diberi pertanyaan terhadap materi pembelajaran., 8) alokasi waktu yang tersedia bisa dimamfaatkan secara optimal.

Pembelajaran gerak dasar lokomotor (PGDL) dengan indikator berlari, berjalan, melompat, meloncat dan merayap dalam bentuk permainan secara perorangan, berpasangan, beregu dan kelasikal. Kelemahan yang harus diperbaiki pada penelitian yang mendatang perlu adanya revisi pada bagian tertentu antara lain adalah: 1) menentukan tingkat kesulitan dari masing-masing gerakan, 2) Variasi gerakan diperbanyak dengan tingkat kesukaran yang variatif, dan 3) menciptakan berbagai model-model permainan yang lebih merangsang anak untuk menyukai kegiatan pembelajaran gerak dasar lokomotor ini.

\section{Simpulan}

1. Pada dasarnya pengembangan model pembelajaran PGDL telah memenuhi kriteria syarat penerapan suatu model pembelajaran yakni: sintaksis (syntax), sistem social (social system), prinsip reaksi (principles of reaksi), sistem pendukung (support system), serta danpak instruksional dan dampak pengiring (instructional and nurturant effects). Sehingga model ini dapat meningkatkan minat siswa terhadap pembelajaran PJOK di sekolah.

2. Bahwa komponen model saling berkaitan antara yang satu dengan yang lainnya, yang artinya model dinyatakan telah valid dari kegiatan uji coba. Sedangkan untuk kepraktisan model dilihat dari nilai rerata keterlaksanaan dari model adalah $=85,90 \%$ yang berarti bahwa tingkat keterlaksanaan model berada pada kategori "sangat tinggi". Sedangkan keefektifan model menunjukkan bahwa nilai rerata aktivitas siswa yakni= 91,64 setelah 
dikomversikan ke dalam tabel penggolongan aktivitas belajar siswa, maka nilai tersebut tergolong dalam ketegori aktivitas belajar "sangat tinggi".

3. Mempedomani persentase hasil tanggapan siswa terhadap pelaksanaan pembelajaran PJOK, secara keseluruhan tanggapan siswa tergolong pada kategori positif. Ini membuktikan pembelajaran PGDL telah membuat siswa belajar lebih semangat, tidak kaku, sesuai dengan cara belajar siswa, berani bertanya, tidak bosan, menyenangkan, menciptakan percaya diri dan lebih mudah memahami materi. Maka pembelajaran penjasorkes PGDL ini layak dan efektif untuk diterapkan.

\section{Rujukan}

Bompa, O. Tudor dan G.Gregory Haff, 1999. Periodezation Teory and Methodologi of Training. USA: Human Kinetict.

Gree, Ken, 2011. Understanding Physical Education. California: SAGE Publication Ltd.

Joiyce, Bruce dan Marsha Weil, Marsha Well dan Emily Calhoun, 2011. Model Of Teching. Yogyakarta: Pustaka Pelajar.

David Gallaheu dan Jhon C Ozman, 2006. Understanding Motor Development, Infants Childrens, Adolescents, Adult. New York: McGROW HILL International Edition.

Rusman, 2012. Model-Model Pembelajaran. Mengembangkan Profesionalisme Guru. Jakarta: Rajawali Pers.

Suherman, Adang dan Hadi Sartono, 2008. Paedagogi Olahraga, Bandung: UPI

W.R Borg \& Gall, M.D. Gall, 2005. Education Research: An Introduction, Eighth Edition. New York: Longman. 